Article

\title{
Parents' Learning Mechanisms for Family Firm Succession: An Empirical Analysis in Spain through the Lens of the Dynamic Capabilities Approach
}

\author{
Natalia Martin-Cruz ${ }^{1}$, Ismael Barros Contreras ${ }^{2, *}$, Juan Hernangómez Barahona ${ }^{1}$ and \\ Héctor Pérez Fernández ${ }^{1}$ \\ 1 School of Economics and Management, University of Valladolid, 47002 Valladolid, Spain; \\ ambiela@eco.uva.es (N.M.-C.); jhernan@eco.uva.es (J.H.B.); hector.perez.fernandez@uva.es (H.P.F.) \\ 2 Department of Management and Industry, Universidad Austral de Chile, Puerto Montt 5480000, Chile \\ * Correspondence: ismaelbarros@uach.cl; Tel.: +56-652203034
}

Received: 20 August 2020; Accepted: 30 September 2020; Published: 6 October 2020

\begin{abstract}
Succession is a concern for most family firms. The literature has addressed succession in family firms from different perspectives. However, there are still unaddressed questions concerning the microfoundations of succession, and there is a need to secure a better understanding of the succession process and what role parents play therein. Using the dynamic capabilities approach, we shed light on the influence of parents' behaviors on successors' intentions. In particular, the paper pursues a twofold aim; first, to analyze the effect of learning mechanisms that parents deliberately use with their children in the family firm on the succession dynamic capability; and second, to explore the impact of this dynamic capability of successor intention to continue in the family firm. We test the model on a sample of potential successors of family firms in Spain. Using partial least squares (PLS) for a sample of 9146 individuals, we confirm the positive impact of the use of parents' deliberate learning mechanisms on succession dynamic capability and, in turn, the positive effect of the created succession dynamic capability on the successor's intention to continue the family firm. Furthermore, we find that perceived self-efficacy fails to have any effect on successor intention.
\end{abstract}

Keywords: succession; empirical-quantitative; structural equation modeling; dynamic capability; parents' learning mechanisms; intentions; family firm

\section{Introduction}

Succession is a worrying issue for family firms [1]. In fact, the biggest challenge facing family firms' survival is succession, with most firms having no plans in this regard. In Spain, as in most European countries, the future challenges facing family firms and the main obstacles to generational change have traditionally involved succession planning and professionalization [2]. However, even though it might seem that the success of the succession will depend on its planning, including the criteria to be met by the successor and how these will be applied, other areas need to be studied for a successful family succession in family firms [3].

Family firm literature has addressed this challenge from different theoretical perspectives, with the focus progressively shifting towards the parents (incumbents). In organizational commitment literature, the succession decision is explained by disentangling the various types of successor commitments and by revisiting the antecedents of each type of commitment using a range of theories and approaches [4]. Furthermore, the social cognitive theory advances our understanding of the antecedents of successor engagement in family firms by theoretically modeling the impact of parental support and psychological control on successors [5]. 
Adopting institutional logic, Richards et al. [6] explored the succession dilemma (successor willingness versus their actual ability) by taking the perspective of the incumbent family member, and suggested that incumbents play an important role in terms of their ability to engage skilled successors in the management of the family firm.

The social exchange perspective considers incumbent-successor relationships and stresses the importance of the quality of those relationships for transferring knowledge during the nurturing phase of succession $[7,8]$. The imprinting theory explains how parents transfer their patterns of behavior in the family firm to their children and how a family's culture can guide family members through a learning process that helps to develop a particular way of thinking [9].

Although some progress has been made in family firm literature, there is still a need to secure a better understanding of the succession process and what role parents play therein. In order to gain deeper insights into these issues, we use the dynamic capabilities approach, which shows the family firm as a bundle of learning mechanisms and dynamic capabilities created across generations [10-12]. From this approach, the parents in the family firm play a role in developing learning mechanisms that will allow successors to forge one of the core dynamic capabilities that can keep the firm within the family [13]. Parents can create the learning mechanisms for their successors by giving them support [5], making them committed to the family firm [4], avoiding any negative imprints [9], and then making them willing to engage in the family firm. Should they succeed, successors will acknowledge the benefits of continuing the family firm.

From the dynamic capabilities approach, we highlight the importance of learning derived from incumbents in the firm. The closeness of the relationships between parents and successors and their simultaneous participation in the family and in the firm's systems creates a unique context where knowledge and learning occur in an idiosyncratic manner, allowing the creation of parents' learning mechanisms. The parent-successor relationship contains the specific conditions to integrate and recombine knowledge and to develop emotional and social mechanisms to preserve this knowledge, which then become part of the successors' specialized knowledge and skills and can enable their engagement with the family firm in the long term and guarantee its sustainability [14].

The aim of this research is to deepen current understanding of what role parents play in successors' intentions to continue the family business, taking the perspective of the successor's perceptions. In particular, the study seeks to understand the influence of parents' learning mechanisms on the succession dynamic capability and, ultimately, on successor intention to become the next generation working in the family firm. Additionally, we control for successor skills, as the literature has suggested that these might influence successor intention.

The contributions of this research are twofold. First, we further current knowledge of succession in family firms by using the dynamic capabilities approach in the creation of successor commitment as an antecedent of successor intentions. Second, we present an empirical study in Spain, a country in which succession is a key problem vis-à-vis preserving family capital over time [2].

The remainder of the study is structured as follows. First, we present the theoretical background and hypotheses. We then explain the methodology and results to emerge from the analyses. Finally, we provide the conclusions and offer a discussion of the results.

\section{Theoretical Background and Hypothesis Development}

The dynamic capabilities approach was conceived to explain the sources of firms' competitive advantages occur over time [15]. This approach emerged as an alternative to existing theories and frameworks in an effort to understand the new sources of firms' competitive advantages [16]. Since its conception, scholars have used it and applied it to identify diverse dynamic capabilities that are relevant to performing in environments that display certain characteristics, avoiding the 'zero-profit condition' [10-12].

The distinctive feature of this approach is the concept of dynamic capabilities, and scholars have been challenged to ascertain its underlying microfoundations [16]. Based on this concept, the approach 
seeks to provide insights into how to compete in uncertain environments in which firms must exploit their knowledge while creating new knowledge in an effort to adapt, integrate, and reconfigure their internal and external organizational skills, resources, and competences [16].

Dynamic capabilities emerge from learning and constitute systematic methods for modifying operating routines [17]. Dynamic capabilities are seen as an organization's capacity to intentionally create, extend, or modify its foundation of resources [18]. Dynamic capabilities allow a firm to extend, modify, or create ordinary capabilities through access to and recombination of knowledge, thereby enabling success over time [17,19-21].

In family literature, scholars recognize that the way in which dynamic capabilities are generated in family firms may differ due to the particular characteristics of the learning process inherent in these firms [22]. Because family members are emotionally, economically, and socially attached to the firm, family firms are expected to be able to develop unique and difficult-to-replicate learning mechanisms. There are family learning mechanisms resulting from family practice and experimentation in the firm that can allow strategic management to be effective. In family firms, dynamic capabilities' orchestration is secured through family learning mechanisms [21], with such mechanisms proving vital as a pre-requisite for family firm survival [23] (See Figure 1).

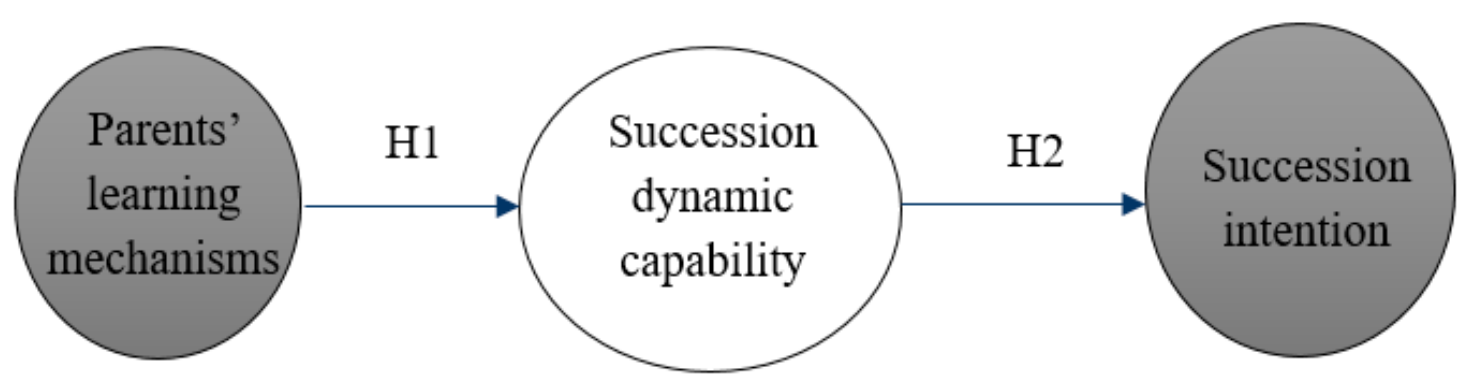

Figure 1. Shows the research model.

Learning in the family firm thus allows the bundle of resources and capabilities provided by the family to be linked and dynamic capabilities to be developed. Once family members acquire new knowledge, develop skills, and bring these into the firm, they can be transferred to the other members of the firm $[12,24]$ and transferred across generations $[25,26]$. Therefore, this specific learning management in family firms recognizes the dynamic component attached to the family's resources and the family firm's ability to secure wealth creation across generations [27].

In particular, parents are involved in the immediate (next) generation's learning about the skills, norms, values, or technical information related to the family firm. Parents act as an active internal stakeholder of successor learning by deliberately guiding them in the family firm learning process [6]. As do other individuals in a firm, successors build their skills by repeatedly executing similar tasks [28] and by figuring out what works and what does not when undertaking tasks in the family firm [17].

Grounded on the dynamic capabilities approach, we define parents' deliberate learning mechanisms as systematic active actions of parents sharing knowledge experience, articulating and codifying family firm knowledge, and preserving the family's socioemotional wealth so that successors learn to solve problems, improve decision-making, stimulate creative ideals, effectively implement organizational objectives, and then assist in renewing organizational capabilities in the family firm (based on Nelson and Winter [29]; Clark and Fujimoto [30]; Teece et al. [21]; Argote [28]; Eisenhardt and Martin [20]; Zollo and Winter [17]; Barros et al. [27]).

These learning mechanisms - as an example of interaction and mutual trust—allow the family firm's values and vision to be transferred to successors [31] and ensure continuity [32,33]. When parents and subsequent generations are involved in management, they exhibit high levels of cohesion and a strong sense of shared purpose [34]. Moreover, symbols or stories about the family and the family firm that parents share with successors and parents' valuable dedication to the firm are elements of the learning process $[9,35]$. In fact, by using these mechanisms, parents are building a succession dynamic 
capability that is strongly anchored in the family firm's culture, shared values, experimentation, and so on [36]. Following Zollo and Winter's [17] definition of a dynamic capability, we define succession dynamic capability as a learned and stable pattern of succession feelings, perceptions, motivations, and commitments through which the family firm systematically generates and modifies its operating routines in pursuit of family firm survival.

Balanced family structures have a positive influence on the family business over time, meaning that when family systems are connected and flexible in family firms, the succession plans prove more effective [37]. Because a learning organization must enable the rapid dissemination of new knowledge laterally and vertically [36], families that balance stability and change, while at the same time working together in a democratic style and sharing roles, might be more able to better create a balanced commitment to the family firm [38]. Parents use their leadership skills to help successors develop their capacities to detect, interpret, and act on any future threats or new opportunities that might emerge in the family firm [36].

Family firm members who simultaneously fulfil the function of owner and manager maintain leadership and learning capabilities that make them worthy of being considered entrepreneurial managers and capable of creating lasting learning mechanisms for future generations that can ensure the sustainability of the succession dynamic capability $[39,40]$. Based on those arguments, we formulate the following hypothesis.

H1. Parents' use of specific deliberate learning mechanisms with successors is positively related to the succession dynamic capability.

The ultimate objective of the family firm is its survival, and for that to occur, successors must be willing to be the next generation attached to running the firm. Therefore, successor's intention to continue the family firm is the first step towards family firm survival. From the dynamic capabilities approach, strong dynamic capabilities are critical to success and survival [41]. In the particular case of family firms and succession, these firms need a strong succession dynamic capability that will allow them to draw on successors who wish to continue the family firm [12,27].

The succession dynamic capability allows successors to deploy their own resources, adjust them as circumstances require, and generate or acquire new ones when needed [42], and allows them to focus on the continuation of the family firm in an effort to preserve company survival. The succession dynamic capability, grounded on successors' feelings, perceptions, motivations, and commitments, is important vis-à-vis creating succession intention. A successor who has acquired the skill to preserve socioemotional wealth [43] and who understands the importance of noneconomic outcomes displays greater potential to develop transgenerational succession intention [38]. A successor who is able to secure organizational autonomy and entrepreneurial desires can relate to the feelings of readiness for succession [16]. Moreover, dynamic capabilities related to succession are associated with people who possess the abilities to develop better strategic practices [9] and achieve long-term profitability and growth [15]. Based on these arguments, we formulate the following hypothesis.

H2. Succession dynamic capability is positively related to succession intention.

\section{Methodology}

\subsection{Sample and Data Collection}

Data were collected from the 2018 Global University Entrepreneurial Spirit Students' Survey (GUESSS), an international research project that investigates the entrepreneurial intentions and activities of students using a geographical and temporal comparison [44-48]. In this case, we use the Spanish version of the questionnaire. The 2018 GUESSS edition investigated and compared entrepreneurial attitudes, intentions, and activities of students at more than 3000 universities from 54 countries. The questionnaire was active from 5 October 2018 to 23 December 2018. In total, 76 Spanish universities participated in GUESSS. Students at the various universities received an e-mail with an invitation 
to participate in a study on their 'future career choice', together with a link to the online survey. This method can be considered suitable to reach students at different universities [49]. In addition, student samples are adequate for entrepreneurial intention research [50].

In Spain, the number of students contacted was 1,537,591 and the valid response rate was $2.2 \%$. In total, 33,278 student responses were collected. Since we are studying succession intention in this research, we are only interested in students whose parents are self-employed and/or a majority owner of a business. The final sample size was, therefore, 9146 students. Of these, the average age is 22.5 years, and $57.6 \%$ are female. These students belong to different fields of study-mainly to engineering $(20.6 \%)$, business/management (18.5\%), and social sciences, such as education, politics, and psychology (15.0\%).

\subsection{Variables and Measures}

All of the measures used in this paper were collected from the GUESSS questionnaire answered by university students. The scales are seven-point Likert scales for all the variables. Below, we explain the measures for each of the dependent and independent variables (Table 1).

Table 1. Construct operationalization.

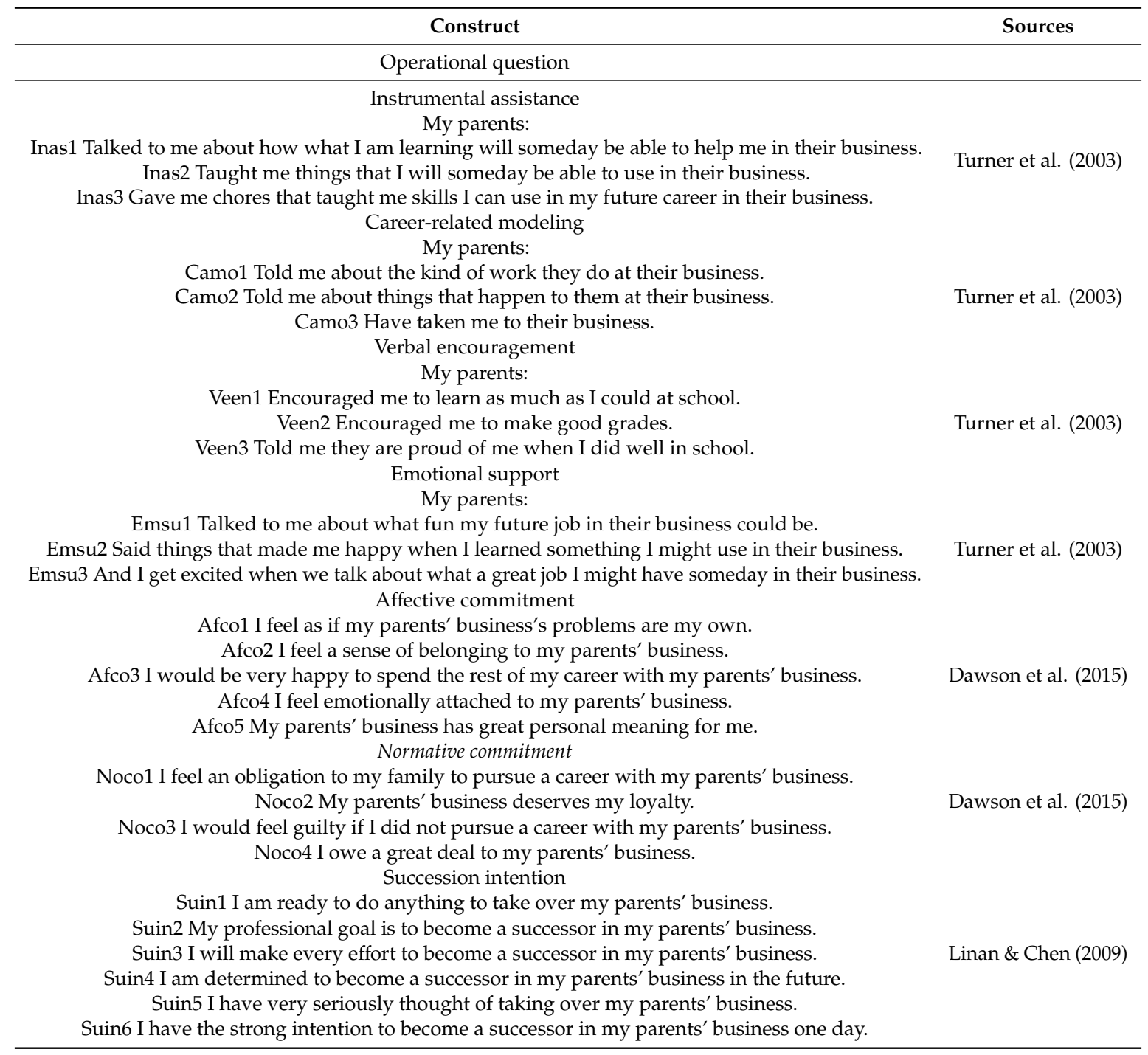

Succession intention: GUESSS uses six items adapted from Liñán and Chen [51] concerning whether students are ready to, intend to, or are determined to be the successor of their parents' 
businesses. Students are asked to answer different questions, such as the extent to which they agree with different statements related to succession.

Parents' learning mechanisms: For these variables, GUESSS employs the Career-Related Parent Support Scale of Turner et al. [52], adapting it for family firms. This scale contains four different groups of items: (1) Instrumental assistance (three items); (2) career-related modeling (three items); (3) verbal encouragement (three items); (3) emotional support (three items). Students were asked to answer different statements related to how much they agree with their parents' behavior towards them while they were growing up.

Succession dynamic capability: As previously mentioned, succession dynamic capability depends on the different succession feelings, perceptions, motivations, and commitments of successors. In this way, succession dynamic capability is operationalized with two different types of commitment: affective and normative. The affective commitment scale consists of five items related to the sense of belonging and to individuals' feelings of being emotionally attached to their parents' family firms. Normative commitment consists of four items concerning individuals' obligation to follow their family firms [4]. Students are asked to respond to different statements in terms of how much they agree with each of them.

Table 1 shows the operationalization constructs and their sources.

\subsection{Control Variables and Common Method Bias}

We introduce different variables as control variables. First, we use gender, since prior studies show that, compared to women, men have a higher preference for entrepreneurial behavior [53-56]. We operationalized this with a dummy variable (Male $=0$; Female $=1)$. Second, self-efficacy refers to individuals' perception of whether they either do or do not possess the capabilities to successfully engage in entrepreneurial behavior [57]. Previous studies in entrepreneurship consider self-efficacy as an important predictor of entrepreneurial intention [58,59], such that we control for this variable. GUESSS adapts previous entrepreneurial self-efficacy scales $[59,60]$ to skills that are more related with the tasks and roles involved in family firms. In particular, GUESSS operationalizes self-efficacy with eight items related to conflict management and to maintaining healthy relationships with family members, employees, and other stakeholders. Lastly, as the final sample is composed of students from different fields of study, we include two dummy variables to control fields of study. In particular, we include a dummy variable for students of engineering or computer sciences/IT $(1=$ engineering or IT fields; $0=$ any other field $)$ and a dummy variable for students of humanities and arts $(1=$ humanities or arts; $0=$ any other field). Previous research shows that students from different fields have different entrepreneurial intentions, attitudes, or behaviors [61-64].

Common method bias is a serious concern when the same individual answers perceptual measures related to dependent and independent variables [65]. In order to assess the severity of common method bias, we conduct a Harman one-factor test [66] with our seven main variables. This test checks whether data variance is mainly attributed to a single factor. We adopt the rule of an eigenvalue of greater than one and find four factors. The highest covariance explained by one factor is only $26.6 \%$. We thus confirm that common method bias is not a concern.

\subsection{Method of Analysis}

We use structural equation modeling (SEM) for our statistical analysis. In particular, we employ the partial least squares (PLS-SEM) approach. PLS-SEM is increasingly being used in the research fields of administration research, strategy, and marketing [67-70], as well as in family firms [71-74]. Recent studies stress the usefulness of the PLS-SEM model as a research tool in the field of family firms $[75,76]$. Following PLS-SEM, the measurement and structural parameters are estimated via an iterative procedure that combines simple and multiple regressions. This avoids any distributional assumption of the observed variables. Consequently, PLS-SEM does not require data normality and does not suffer from the indeterminacy problems associated with other modeling techniques [77]. 
In addition, we choose PLS-SEM because it can handle both reflective and formative constructs [78], added to which it allows both first-order and second-order constructs to be modelled. All first-order constructs are reflective. We model the parent learning mechanism as a second-order construct in a reflective-formative way.

\section{Results}

\subsection{Measurement Model}

The measurement model presents the parameters associated with the constructs, and they are all reflective constructs. In PLS-SEM, the reflective indicators are determined by the construct and are covariate at this level [79]. The measurement model is evaluated by studying the reliability of each item and the internal consistency, as well as the convergent validity (Table 2) and discriminant validity (Table 3) [80]. Table 2 summarizes the parameters of the measurement model.

Table 2. Latent variable, items' measures, composite reliability, average variance extracted (AVE), and Cronbach's Alpha.

\begin{tabular}{|c|c|c|c|c|c|}
\hline Construct/Indicator & Factor Loading & $\mathrm{t}$-Statistic & Composite Reliability & AVE & Cronbach's Alpha \\
\hline $\begin{array}{l}\text { Instrumental } \\
\text { assistance }\end{array}$ & & & 0.931 & 0.819 & 0.889 \\
\hline Inas1 & 0.862 & 245.035 & & & \\
\hline Inas2 & 0.930 & 527.440 & & & \\
\hline Inas3 & 0.921 & 466.122 & & & \\
\hline $\begin{array}{l}\text { Career-related } \\
\text { modeling }\end{array}$ & & & 0.939 & 0.836 & 0.902 \\
\hline Camo1 & 0.929 & 443.763 & & & \\
\hline Camo2 & 0.935 & 511.987 & & & \\
\hline Camo3 & 0.878 & 222.072 & & & \\
\hline $\begin{array}{c}\text { Verbal } \\
\text { encouragement }\end{array}$ & & & 0.920 & 0.793 & 0.870 \\
\hline Veen1 & 0.892 & 195.973 & & & \\
\hline Veen2 & 0.910 & 215.001 & & & \\
\hline Veen 3 & 0.869 & 198.934 & & & \\
\hline Emotional support & & & 0.934 & 0.826 & 0.895 \\
\hline Emsu1 & 0.913 & 399.114 & & & \\
\hline Emsu2 & 0.902 & 372.258 & & & \\
\hline Emsu3 & 0.912 & 397.549 & & & \\
\hline $\begin{array}{c}\text { Affective } \\
\text { commitment }\end{array}$ & & & 0.917 & 0.689 & 0.887 \\
\hline Afco1 & 0.730 & 122.656 & & & \\
\hline Afco2 & 0.863 & 254.478 & & & \\
\hline Afco3 & 0.785 & 187.367 & & & \\
\hline Afco 4 & 0.892 & 339.628 & & & \\
\hline Afco5 & 0.870 & 294.206 & & & \\
\hline $\begin{array}{l}\text { Normative } \\
\text { commitment }\end{array}$ & & & 0.895 & 0.684 & 0.841 \\
\hline Noco1 & 0.905 & 427.959 & & & \\
\hline Noco2 & 0.857 & 228.468 & & & \\
\hline Noco3 & 0.884 & 306.890 & & & \\
\hline Noco4 & 0.634 & 85.002 & & & \\
\hline Succession intention & & & 0.975 & 0.868 & 0.969 \\
\hline Suin 1 & 0.876 & 214.493 & & & \\
\hline Suin2 & 0.946 & 464.376 & & & \\
\hline Suin3 & 0.958 & 570.326 & & & \\
\hline Suin4 & 0.957 & 567.014 & & & \\
\hline Suin5 & 0.902 & 253.924 & & & \\
\hline Suin6 & 0.947 & 425.265 & & & \\
\hline
\end{tabular}


Table 3. Inter-construct correlations and average variance extracted (AVE).

\begin{tabular}{lrrrrrrr}
\hline \multicolumn{1}{c}{ Construct } & $\mathbf{1}$ & $\mathbf{2}$ & $\mathbf{3}$ & $\mathbf{4}$ & $\mathbf{5}$ & $\mathbf{6}$ & $\mathbf{7}$ \\
\hline 1. Instrumental assistance & $\mathbf{0 . 9 0 5}$ & & & & & & \\
2. Career-related modeling & 0.515 & $\mathbf{0 . 9 1 4}$ & & & & & \\
3. Verbal encouragement & 0.110 & 0.369 & $\mathbf{0 . 8 9 0}$ & & & & \\
4. Emotional support & 0.662 & 0.297 & 0.081 & $\mathbf{0 . 9 0 9}$ & & & \\
5. Affective commitment & 0.564 & 0.345 & 0.052 & 0.548 & $\mathbf{0 . 8 3 0}$ & & \\
6. Normative commitment & 0.564 & 0.301 & -0.014 & 0.550 & 0.739 & $\mathbf{0 . 8 2 7}$ & \\
7. Succession intention & 0.457 & 0.183 & -0.064 & 0.505 & 0.622 & 0.666 & $\mathbf{0 . 9 3 1}$ \\
\hline
\end{tabular}

The elements in the diagonal belong to the root of the AVE.

The internal reliability of each item is determined by item loadings and is expressed as the percentage of the variance of the item relative to the construct. In order to obtain good item reliability, the load must be greater than 0.7 [81]. All loadings are above 0.7 , with the exception of one normative commitment construct, which has loads close to 0.6, a measurement still deemed acceptable [82].

The internal consistency of the constructs is evaluated by determining Cronbach's Alpha and composite reliability. The indicators exceed 0.8 for Cronbach's Alpha and 0.8 for composite reliability, indicating that both measurements are acceptable [83]. The convergent validity of the construct is expressed in the degree that all the items in a construct are measured by the same concept and is evaluated by examining the average variance extracted (AVE). In our analysis, the AVE indicator exceeds 0.6, as recommended by Fornell and Larcker [84].

Discriminant validity is evaluated by examining the degree to which the root of the AVE is higher than the co-related inter-construct. Table 3 shows this relation.

In sum, the tests show that all the indicators display reasonable measurement properties.

As stated, we treat the variable parents' learning mechanism as a second-order construct with a formative nature. We examine how significant the contribution of each dimension is to the second-order construct. Following Becker et al. [85], we use the repeated indicator approach to estimate the measurement models for instrumental assistance, career-related modeling, verbal encouragement, and emotional support. Table 4 shows that the outer weights of all the facets that belong to parents' learning mechanisms are significant, confirming that the fit of the formative measurement models is good. We then check for multicollinearity using the variance inflation factor. The values of the respective dimensions are below the cut-off value of 5 , indicating no collinearity concerns.

Table 4. Quality criteria of second-order measurement.

\begin{tabular}{ccc}
\hline Formative Second-Order Construct Facets/Components & Outer Weights & VIF \\
\hline Parent learning mechanisms & & \\
Instrumental assistance & $0.448^{* *}$ & 2.248 \\
Career-related modeling & $0.315^{* *}$ & 1.585 \\
Verbal encouragement & $0.082^{* *}$ & 1.171 \\
Emotional support & $0.426^{* *}$ & 1.792 \\
\hline Bias-corrected bootstrap significance levels: ${ }^{* *} p<0.01$ (one-tailed test); VIF = variance inflation factor.
\end{tabular}

\subsection{Structural Model}

We use Smart PLS 3.0 to validate our model by bootstrapping 1000 randomly generated subsamples to determine the significance of the Beta coefficients $(\beta)$. Table 5 shows the results.

Table 5 shows that parent learning mechanisms positively and significantly influence succession dynamic capability, with a coefficient of $0.600(t=77.058)$ (affective commitment) and a coefficient of $0.582(t=72.788)$ (normative commitment). These results provide evidence of the direct impact of parent learning mechanisms through parents' knowledge transfer on potential successors in family firms. Parents are able to forge succession dynamic capabilities by stimulating successors' affective 
and normative commitment, and by creating lasting learning mechanisms for future generations, they ensure the succession dynamic capability $[39,40]$. These results support H1.

Table 5. Standardized parameter estimates.

\begin{tabular}{|c|c|c|c|}
\hline Hypotheses & Path Coefficient & $t$-Value & Outcome \\
\hline $\begin{array}{c}\text { Parent learning mechanisms } \rightarrow \text { Succession dynamic } \\
\text { capability (Affective commitment) }\end{array}$ & 0.600 & 77.058 * & \multirow{2}{*}{ H1 Supported } \\
\hline $\begin{array}{c}\text { Parent learning mechanisms } \rightarrow \text { Succession dynamic } \\
\text { capability (Normative commitment) }\end{array}$ & 0.582 & $72.788 *$ & \\
\hline $\begin{array}{l}\text { Succession dynamic capability (Affective commitment) } \rightarrow \\
\text { Succession intention }\end{array}$ & 0.281 & 20.804 * & \multirow{2}{*}{ H2 Supported } \\
\hline $\begin{array}{l}\text { Succession dynamic capability (Normative commitment) } \rightarrow \\
\text { Succession intention }\end{array}$ & 0.451 & $33.371 *$ & \\
\hline \multicolumn{4}{|l|}{ Control relationships } \\
\hline Gender $\rightarrow$ Succession intention & -0.042 & $5.233 *$ & \\
\hline Self-efficacy $\rightarrow$ Succession intention & 0.003 & 0.481 & \\
\hline Engineering/IT $\rightarrow$ Succession intention & -0.003 & 0.415 & \\
\hline Humanities/Arts $\rightarrow$ Succession intention & -0.032 & $4.688^{*}$ & \\
\hline$R^{2}$ of Succession Intention & & 0.483 & \\
\hline$R^{2}$ of Affective Commitment & & 0.360 & \\
\hline$R^{2}$ of Normative Commitment & & 0.338 & \\
\hline
\end{tabular}

In addition, Table 5 summarizes the results that support H2. Succession dynamic capability (affective and normative commitment) positively and significantly affects the succession intention, with a coefficient of $0.281(t=20.804)$ (affective commitment) and a coefficient of $0.451(t=33.371)$ (normative commitment). These results confirm that succession dynamic capability, grounded on the succession feelings, perceptions, motivations, and commitments of successors, proves relevant vis-à-vis creating the succession intention and, therefore, granting family firm survival for at least one more generation.

The study includes different variables as control variables. Only gender and students' study area (humanities and arts) were found to be significant with regard to succession intention, with a coefficient of $-0.042(t=5.233)$ and a coefficient of $-0.032(t=4.688)$, respectively. These results suggest that gender (male/female) affects succession intention. The negative coefficient implies that females display less intention to continue in the family firm than males. This finding is in line with previous empirical and theoretical research [53-56]. As regards the field of study, humanities and arts students exhibit less intention to continue the family firm than students from other disciplines. In previous research, results show that students from these specific fields display less entrepreneurial intention than the rest [61-64]. As for the perceived self-efficacy variable, the results fail to show any effect on successor intention. This is also an interesting result, since the successor's locus of control, or their perceived lack of marketable skills, has been considered in the literature as playing a role in succession intention [86,87].

Finally, we state that the structural model evaluation displays good predictive qualities, weight, and size of variables and relationships. The results have been replicated through a linear regression (IBM SPSS 24) and do not significantly differ with respect to those obtained using PLS-SEM modeling for any of the relationships considered. We also conducted a multi-group analysis to test whether there are any significant differences between students in their final or initial years. Results show that there are no significant differences in any of the relationships considered between these two groups of university students. 


\subsection{Robustness Analysis}

We include two different robustness analyses in this study. First, because Spain is made up of many different regions, each of which has its own particularities, we decided to look at one of the regions in order to demonstrate that the previous results are robust for a smaller sample size. Specifically, we studied Castilla y León (which has four public and four private universities), and which provided a total sample size of 2899 students. Since we are only interested in students whose parents are self-employed and/or are majority owners of a business, the final sample size comprised 835 students. As shown in Table 6, the results for this region are very similar when compared with the results of the sample for Spain as a whole.

Table 6. Standardized parameter estimates for Castilla y León.

\begin{tabular}{|c|c|c|c|}
\hline Hypotheses & Path Coefficient & $t$-Value & Outcome \\
\hline $\begin{array}{l}\text { Parent learning mechanisms } \rightarrow \text { Succession dynamic } \\
\text { capability (Affective commitment) }\end{array}$ & 0.618 & $26.759 * *$ & \multirow{2}{*}{ H1 Supported } \\
\hline $\begin{array}{l}\text { Parent learning mechanisms } \rightarrow \text { Succession dynamic } \\
\text { capability (Normative commitment) }\end{array}$ & 0.605 & $25.148 * *$ & \\
\hline $\begin{array}{l}\text { Succession dynamic capability (Affective commitment) } \rightarrow \\
\text { Succession intention }\end{array}$ & 0.242 & $5.134 *$ & \multirow[b]{2}{*}{ H2 Supported } \\
\hline $\begin{array}{l}\text { Succession dynamic capability (Normative commitment) } \rightarrow \\
\text { Succession intention }\end{array}$ & 0.452 & $9.493^{* *}$ & \\
\hline Control relationships & & & \\
\hline Gender $\rightarrow$ Succession intention & -0.041 & 1.489 & \\
\hline Self-efficacy $\rightarrow$ Succession intention & -0.008 & 0.331 & \\
\hline Engineering/IT $\rightarrow$ Succession intention & 0.038 & 1.309 & \\
\hline Humanities/Arts $\rightarrow$ Succession intention & -0.064 & $2.802 * *$ & \\
\hline$R^{2}$ of Succession Intention & 0.437 & & \\
\hline$R^{2}$ of Affective Commitment & 0.385 & & \\
\hline$R^{2}$ of Normative Commitment & 0.369 & & \\
\hline
\end{tabular}

Table 6 shows that parent learning mechanisms positively and significantly influence succession dynamic capability, with a coefficient of $0.618(t=26.759)$ (affective commitment) and a coefficient of $0.605(t=25.148)$ (normative commitment). These results provide evidence of the direct impact of parent learning mechanisms on succession dynamic capabilities for the whole sample. In addition, succession dynamic capability (affective and normative commitment) positively and significantly affects the succession intention, with a coefficient of $0.242(t=5.134)$ (affective commitment) and a coefficient of $0.452(t=9.493)$ (normative commitment). Second, in our previous study, we considered students whose parents are self-employed and those who are majority owners of a business. However, there might be differences between these two groups, since, for example, being the child of a business owner could involve greater commitment than being the child of a self-employed person. Therefore, we decided to conduct a multi-group analysis (Smart PLS 3.0) in order to test whether there are any significant differences between the two groups. In terms of sample size, the self-employed group contains 5485 individuals, while the majority owner group contains 3544 individuals, such that 117 answers are missing. Table 7 shows the $\beta$ coefficients of the two groups and the differences, including whether or not these differences are significant.

Table 7 summarizes the multi-group analysis results. We see that there are significant differences between students whose parents are self-employed and those whose parents own the majority of a firm. In fact, the significant differences between these two groups are based on the structural paths "Succession dynamic capability (affective commitment) $\rightarrow$ Succession intention" and "succession dynamic capability (normative commitment) $\rightarrow$ succession intention", with a coefficient of 0.063 $(t=2.238)$ and a coefficient of $0.082(t=2.796)$, respectively. These results suggest that succession affective commitment is significantly more important for individuals whose parents are the majority 
owners of a firm. This type of firm is strongly based on affective family ties that constitute an invisible force that unites family members towards a common goal: the desire for the firm to succeed and transcend through family generations. Affective commitment is, therefore, the most important and significant in the succession process in firms whose parents own the majority of a firm $[4,16]$.

Table 7. Standardized parameter estimates.

\begin{tabular}{|c|c|c|c|}
\hline Hypotheses & $\begin{array}{l}\text { Path Coefficient } \\
\text { Self-Employed }\end{array}$ & $\begin{array}{l}\text { Path Coefficient } \\
\text { Firm Owners }\end{array}$ & $\begin{array}{c}\text { Difference } \\
\text { Between Groups }\end{array}$ \\
\hline $\begin{array}{l}\text { Parent learning mechanisms } \rightarrow \text { Succession } \\
\text { dynamic capability (Affective commitment) }\end{array}$ & 0.568 & 0.577 & 0.009 \\
\hline $\begin{array}{c}\text { Parent learning mechanisms } \rightarrow \text { Succession } \\
\text { dynamic capability (Normative commitment) }\end{array}$ & 0.548 & 0.577 & 0.029 \\
\hline $\begin{array}{l}\text { Succession dynamic capability (Affective } \\
\text { commitment) } \rightarrow \text { Succession intention }\end{array}$ & 0.263 & 0.327 & $0.063 *$ \\
\hline $\begin{array}{l}\text { Succession dynamic capability (Normative } \\
\text { commitment) } \rightarrow \text { Succession intention }\end{array}$ & 0.469 & 0.388 & $0.082^{* *}$ \\
\hline \multicolumn{4}{|l|}{ Control relationships } \\
\hline Gender $\rightarrow$ Succession intention & -0.048 & -0.032 & 0.016 \\
\hline Self-efficacy $\rightarrow$ Succession intention & 0.004 & 0.005 & 0.001 \\
\hline Engineering/IT $\rightarrow$ Succession intention & -0.008 & 0.011 & 0.019 \\
\hline Humanities/Arts $\rightarrow$ Succession intention & -0.037 & -0.023 & 0.014 \\
\hline
\end{tabular}

\section{Conclusions and Discussion}

\subsection{Conclusions}

Our results indicate that parents deliberately design family learning mechanisms to create a succession dynamic capability, and that this capability positively affects successor intention to remain in the family firm. Our research thus extends family firm succession literature by applying the dynamic capabilities approach. Succession is a topic dealt with by several scholars, despite which there is still a need to theoretically and empirically locate the proximate causes at the micro-level of analysis [88].

Our research suggests that the dynamic capabilities approach helps to understand parents' role in family firm succession. Following on from previous research [13], we add more empirical evidence in the analysis of succession and advance in other areas of research in family firm literature from a dynamic capabilities approach [10-12,24,27,89-91].

As stated, one of the open questions in family firm research involves understanding what role parental behavior plays in the next generation's willingness to join the family firm [88]. Theoretically, authors have recognized the importance of specifically transferring incumbent family firm member knowledge in order to generate successors' learning over time in a non-linear and simple fashion, taking into account other internal and external factors that affect successors' capabilities. In this research, we show that parents are crucial in succession dynamic capability creation by using specific learning mechanisms within the family firm. Parents help successors to sense the opportunities that the family firm might provide them with if they scan, create, learn, and interpret, and are able to seize the potential investments required for them to become involved in the family firm [15]. Moreover, this dynamic capability enables successors to develop their intention to continue the family firm. The notion of parents' involvement in the succession process as a predictor of successor intention is thus gaining strength, as suggested by other researchers [7].

\subsection{Discussion}

The development and evolution of the succession dynamic capability must invoke mechanisms that go beyond the semi-automatic stimulus response process [17]. In family firms, there is a learning 
process wherein parents know that tacit experiential knowledge is not enough to develop a succession dynamic capability. Therefore, they specifically organize learning mechanisms in an effort to convey and codify their knowledge to their successors, doing so by talking with them and making them aware of how the family firm works by emotionally sharing their experiences and ideas about the firm. They also seek to codify their knowledge by explicitly showing how they make decisions and how the family firm works. Consequently, the succession process could be explained in the tradition of the evolutionary paradigm that Zollo and Winter [17] employ to explain the evolution of organizational learning-"variation-selection-retention". Incumbents become aware of the need for succession as well as of possible changes in the family firm, and so commence a process of selecting the potential successor, whose intention to stay in the family firm they seek to enhance through a deliberate process of creating learning mechanisms that are designed to engender the succession dynamic capability.

\section{Implications, Limitations, and Further Research}

This research has some implications for theory and practice, as well as limitations that motivate possible lines for further research.

\subsection{Implications for Theory}

As the results suggest, parents have a key role to play in the succession process. Scholars must, therefore, specifically analyze the process of acquisition, transfer, and integration of knowledge between parents and successors, and explain how parents are able to combine those in a co-evolutive manner with emotions (socioemotional wealth). In this way, we support the results of Casprini et al. [92], who were the first to study the specific challenges facing a family firm when acquiring and transferring knowledge.

Using dynamic capabilities, we present a new empirical evidence approach about one particular aspect of family firms-namely, succession. The dynamic capabilities approach might play an important role in explaining the process of succession in family firms and in explaining their survival or disappearance. The dynamic capabilities approach has value if considered as a single approach or when combined with other traditional family firm theories. Scholars are still studying the process of knowledge creation, transfer, and retention in family firms [92], and the dynamic capabilities approach can complement this research, since it focuses on the microelements [93] of such learning processes.

Parents' role in the learning process and, therefore, in the creation of dynamic capabilities, other than those concerning succession, should be included in research as a key element of family firm success and survival. How parents' knowledge is managed needs to be studied as a driver of dynamic capabilities that influences learning in family firms. These firms must learn not only about the business itself, but also about the specific characteristics of the family and how family members run the firm.

\subsection{Implications for Practice}

Family firms still need to work on the processes through which succession might pose both a challenge and an opportunity for future generations. Parents (incumbents) must be aware of any (external and internal) factors that might affect the skills and attitudes that successors need to maintain succession intention, and they must constantly consider how they can positively influence successors' intentions to continue the family firm. They should, therefore, review how their learning mechanisms must evolve in order to allow the succession dynamic capability to develop over time.

The external factors that make successors develop new skills and attitudes include changes in the sociological environment that affect people's motivations, or technological or economic disruptive fluctuations that push the firm to adapt to the new competitive playing field. Internal factors include the potential rapid success of the family firm, which might make successors believe that reaching such a dominant situation is routinized in the firm and occurs with semi-automatic responses.

Moreover, family firm owners need to take greater care about the affective element of the succession dynamic capability than those who are self-employed. The emotional characteristics of incumbents and 
successors are more relevant in the succession process for family firm owners. As a result, the emotional aspects of parents' learning mechanisms need to be developed further, since such aspects might have a greater impact on the learning mechanism and, therefore, influence successor intention to continue in the firm.

Finally, successor self-efficacy might not be a major concern for parents as they develop the learning mechanism. If correctly activated from incumbent to successor through efficient learning mechanisms, knowledge will offset the negative impact of other factors that might curb successors' intentions to remain in the family firm.

\subsection{Limitations and Further Research}

This study has several limitations. First, the analysis focuses on only one country, Spain. Therefore, any conclusions should be used carefully in other countries, as researchers suggest that cultural embeddedness affects the role played by family in the firm [6]. However, we performed several robustness checks in different contexts in Spain and found similar results. There is also the possibility of extending the research to other countries involved in the GUESSS project.

The results may be affected by self-selection bias. Since the GUESSS survey is voluntary, individuals answering this survey are likely to display a more entrepreneurial personality and, therefore, their succession intentions are likely to be higher than those who do not answer the survey. However, there are many different studies based on the GUESSS survey, and which are considered to be appropriate [45-47].

As regards the measures, there is ample room for improvement. In particular, the measures we use to gauge succession dynamic capabilities could be enhanced. This study offers an initial approach to assessing succession dynamic capabilities in the family firm, although another evaluation of this concept could be applied in further research.

The sample we use in the study involves university students. Incumbents' level of education is related to their accessibility to corporate logic, since this tends to be greater at higher levels of education [6]. Even though we control for the effect of incumbent self-efficacy on successor intention, it would be interesting to test the model in a large sample of the population that includes other levels of education.

In addition to improving upon the limitations of this research, further inquiry might seek to extend the analysis of succession and the roles that each individual plays in the learning process from incumbent to successor over time. This objective might benefit from using the case study method with family firms in which the succession process is actually being considered by the family members. Furthermore, consideration should be given to conducting a longitudinal study where the evolution of the dynamic capabilities of the potential successor may be studied over time [94].

Analysis of successor intention might also be extended by exploring the actual successor and by comparing factors affecting intention to those affecting final successor behavior. In fact, this comparison might provide information concerning which elements distinguish intention from actual behavior.

Author Contributions: Motivation, N.M.-C., and I.B.C.; conceptualization, N.M.-C., and J.H.B.; methodology, N.M.-C., and H.P.F.; analysis, H.P.F, and I.B.C.; discussion and implications, N.M.-C., and J.H.B. All authors contributed to the writing and review of this article. All authors have read and agreed to the published version of the manuscript.

Funding: The authors want to acknowledge the financial support of ECO2016-78128-P project, funded by MINECO.

Conflicts of Interest: The authors declare no conflict of interest.

\section{References}

1. De Massis, A.; Chua, J.H.; Chrisman, J.J.; Chua, J.H. Factors Preventing Intra-Family Succession. Fam. Bus. Rev. 2008, 21, 183-199. [CrossRef]

2. Corona, J. La Imagen de la Empresa Familiar en España; Instituto de la Empresa Familiar: Madrid, España, 2006.

3. Corona, J. La Empresa Familiar en España; Instituto de la Empresa Familiar: Madrid, España, 2015. 
4. Sharma, P.; Irving, P.G. Four Bases of Family Business Successor Commitment: Antecedents and Consequences. Entrep. Theory Pract. 2005, 29, 13-33. [CrossRef]

5. Garcia, P.R.J.M.; Sharma, P.; De Massis, A.; Wright, M.; Scholes, L. Perceived Parental Behaviors and Next-Generation Engagement in Family Firms: A Social Cognitive Perspective. Entrep. Theory Pract. 2018, 43, 224-243. [CrossRef]

6. Richards, M.; Kammerlander, N.; Zellweger, T. Listening to the Heart or the Head? Exploring the "Willingness Versus Ability" Succession Dilemma. Fam. Bus. Rev. 2019, 32, 330-353. [CrossRef]

7. Daspit, J.J.; Holt, D.T.; Chrisman, J.J.; Long, R.G. Examining Family Firm Succession From a Social Exchange Perspective. Fam. Bus. Rev. 2015, 29, 44-64. [CrossRef]

8. Lee, J.S.K.; Zhao, G.; Lu, F. The Effect of Value Congruence Between Founder and Successor on Successor's Willingness: The Mediating Role of the Founder-Successor Relationship. Fam. Bus. Rev. 2019, 32, 259-276. [CrossRef]

9. Kidwell, R.E.; Eddleston, K.A.; Kellermanns, F.W. Learning bad habits across generations: How negative imprints affect human resource management in the family firm. Hum. Resour. Manag. Rev. 2018, 28, 5-17. [CrossRef]

10. Chirico, F.; Nordqvist, M. Dynamic capabilities and trans-generational value creation in family firms: The role of organizational culture. Int. Small Bus. J. Res. Entrep. 2010, 28, 487-504. [CrossRef]

11. Chirico, F.; Nordqvist, M.; Colombo, G.; Mollona, E. Simulating dynamic capabilities and value creation in family firms: Is paternalism an 'asset' or 'liability'? Fam. Bus. Rev. 2012, 25, 318-338. [CrossRef]

12. Chirico, F.; Salvato, C. Knowledge Integration and Dynamic Organizational Adaptation in Family Firms. Fam. Bus. Rev. 2008, 21, 169-181. [CrossRef]

13. Cabrera, M.K.-S.; García-Almeida, D.J.; De Saá-Pérez, P. A Dynamic Network Model of the Successor's Knowledge Construction From the Resource- and Knowledge-Based View of the Family Firm. Fam. Bus. Rev. 2018, 31, 178-197. [CrossRef]

14. Alonso, A.D.; Kok, S. Adapting through learning and knowledge acquisition: The cases of four global family firms. J. Fam. Bus. Manag. 2018, 8, 274-292. [CrossRef]

15. Teece, D.J. Explicating dynamic capabilities: The nature and microfoundations of (sustainable) enterprise performance. Strateg. Manag. J. 2007, 28, 1319-1350. [CrossRef]

16. Cabrera-Suárez, M.K.; Martín-Santana, J.D. Successor's commitment and succession success: Dimensions and antecedents in the small Spanish family firm. Int. J. Hum. Resour. Manag. 2012, 23, 2736-2762. [CrossRef]

17. Zollo, M.; Winter, S.G. Deliberate Learning and the Evolution of Dynamic Capabilities. Organ. Sci. 2002, 13, 339-351. [CrossRef]

18. Helfat, C.E.; Finkelstein, S.; Mitchell, W.; Peteraf, M.A.; Sing, H.; Teece, D.J.; Winter, S.G. Dynamic Capabilities: Understanding Strategic Change in Organizations; Blackwell: Oxford, UK, 2007.

19. Collis, D.J. Research Note: How Valuable are Organizational Capabilities? Strateg. Manag. J. 1994, 15, 143-152. [CrossRef]

20. Eisenhardt, K.M.; Martin, J.A. Dynamic capabilities: What are they? Strateg. Manag. J. 2000, 21, $1105-1121$. [CrossRef]

21. Teece, D.J.; Pisano, G.; Shuen, A. Dynamic capabilities and strategic management. Strateg. Manag. J. 1997, 18, 509-533. [CrossRef]

22. Sánchez, V.-F.; Maseda, A.; Iturralde, T. The role of internal social capital in organizational innovation. An empirical study of family firms. Eur. Manag. J. 2014, 32, 950-962. [CrossRef]

23. Lindow, C.M.; Stubner, S.; Wulf, T. Strategic fit within family firms: The role of family influence and the effect on performance. J. Fam. Bus. Strateg. 2010, 1, 167-178. [CrossRef]

24. Chirico, F. The accumulation process of knowledge in family firms. Electron. J. Fam. Bus. Stud. 2007, 1, 62-90.

25. Barach, J.A.; Ganitsky, J. Successful Succession in Family Business. Fam. Bus. Rev. 1995, 8, 131-155. [CrossRef]

26. Ward, J.L. Keeping the Family Business Healthy: How to Plan for Continuing Growth, Profitability, and Family Leadership; Jossey Bass Inc.: San Francisco, CA, USA, 1987.

27. Barros, I.-C.; Hernangómez, J.; Martin, N.-C. A theoretical model of strategic management of family firms. A dynamic capabilities approach. J. Fam. Bus. Strateg. 2016, 7, 149-159. [CrossRef]

28. Lant, T.K.; Argote, L. Organizational Learning: Creating, Retaining, and Transferring Knowledge. Adm. Sci. Q. 2000, 45, 622. [CrossRef] 
29. Nelson, R.R.; Winter, S.G. An Evolutionary Theory of Economic Change; Harvard University Press: Boston, MA, USA, 1982.

30. Clark, K.B.; Fujimoto, T. Product Development Performance: Strategy, Organization, and Management in the World Auto Industry; Harvard Business School Press: Boston, Boston, MA, USA, 1991.

31. Sirmon, D.G.; Hitt, M.A. Managing Resources: Linking Unique Resources, Management, and Wealth Creation in Family Firms. Entrep. Theory Pract. 2003, 27, 339-358. [CrossRef]

32. Konopaski, M.; Jack, S.; Hamilton, E. How Family Business Members Learn About Continuity. Acad. Manag. Learn. Educ. 2015, 14, 347-364. [CrossRef]

33. Pieper, T.M.; Smith, A.D.; Kudlats, J.; Astrachan, J.H. Article commentary: The persistence of multifamily firms: Founder imprinting, simple rules, and monitoring processes. Entrep. Theory Pract. 2015, 39, 1313-1337. [CrossRef]

34. Gómez, L.R.-M.; Larraza, M.-K.; Makri, M. The determinants of executive compensation in family-controlled public corporations. Acad. Manag. J. 2003, 46, 226-237.

35. Astrachan, J.H.; Klein, S.B.; Smyrnios, K.X. The F-PEC Scale of Family Influence: A Proposal for Solving the Family Business Definition Problem1. Fam. Bus. Rev. 2002, 15, 45-58. [CrossRef]

36. Schoemaker, P.J.H.; Heaton, S.; Teece, D. Innovation, Dynamic Capabilities, and Leadership. Calif. Manag. Rev. 2018, 61, 15-42. [CrossRef]

37. Daspit, J.J.; Long, R.G.; Pearson, A.W. How familiness affects innovation outcomes via absorptive capacity: A dynamic capability perspective of the family firm. J. Fam. Bus. Strateg. 2019, 10, 133-143. [CrossRef]

38. Daspit, J.J.; Madison, K.; Barnett, T.; Long, R.G. The emergence of bifurcation bias from unbalanced families: Examining HR practices in the family firm using circumplex theory. Hum. Resour. Manag. Rev. 2018, 28, 18-32. [CrossRef]

39. Teece, D.; Peteraf, M.; Leih, S. Dynamic Capabilities and Organizational Agility: Risk, Uncertainty, and Strategy in the Innovation Economy. Calif. Manag. Rev. 2016, 58, 13-35. [CrossRef]

40. Teece, D.J. The Foundations of Enterprise Performance: Dynamic and Ordinary Capabilities in an (Economic) Theory of Firms. Acad. Manag. Perspect. 2014, 28, 328-352. [CrossRef]

41. Teece, D.J. Dynamic Capabilities: Routines versus Entrepreneurial Action. J. Manag. Stud. 2012, 49, $1395-1401$. [CrossRef]

42. Teece, D.J.; Al-Aali, A.Y. Knowledge, entrepreneurship, and capabilities: Revising the theory of the MNE. Universia Bus. Rev. 2013, 40, 18-32.

43. Gómez, L.R.-M.; Haynes, K.T.; Núñez-Nickel, M.; Jacobson, K.J.L.; Moyano-Fuentes, J. Socioemotional Wealth and Business Risks in Family-controlled Firms: Evidence from Spanish Olive Oil Mills. Adm. Sci. Q. 2007, 52, 106-137. [CrossRef]

44. Sieger, P.; Fueglistaller, U.; Zellweger, T. Student Entrepreneurship across the Globe: A look at Intentions and Activities; KMU-HSG, University of St. Gallen: St.Gallen, Switzerland, 2014.

45. Brändle, L.; Berger, E.S.C.; Golla, S.; Kuckertz, A. I am what I am-How nascent entrepreneurs' social identity affects their entrepreneurial self-efficacy. J. Bus. Ventur. Insights 2017, 9, 17-23. [CrossRef]

46. Criaco, G.; Sieger, P.; Wennberg, K.; Chirico, F.; Minola, T. Parents' performance in entrepreneurship as a "double-edged sword" for the intergenerational transmission of entrepreneurship. Small Bus. Econ. 2017, 49, 841-864. [CrossRef]

47. Lopez, T.; Alvarez, C. Influence of university-Related factors on students' entrepreneurial intentions. Int. J. Entrep. Ventur. 2019, 11, 521-540. [CrossRef]

48. Moreno, J.-G.; Gómez, E.-A.; Andreis, R.C.-D. Parental role models and entrepreneurial intentions in Colombia. J. Entrep. Emerg. Econ. 2019, 12, 413-429. [CrossRef]

49. Dillman, D.A.; Phelps, G.; Tortora, R.; Swift, K.; Kohrell, J.; Berck, J.; Messer, B.L. Response rate and measurement differences in mixed-mode surveys using mail, telephone, interactive voice response (IVR) and the Internet. Soc. Sci. Res. 2009, 38, 1-18. [CrossRef]

50. Krueger, N.F.; Reilly, M.D.; Carsrud, A.L. Competing models of entrepreneurial intentions. J. Bus. Ventur. 2000, 15, 411-432. [CrossRef]

51. Liñán, F.; Chen, Y.-W. Development and Cross-Cultural Application of a Specific Instrument to Measure Entrepreneurial Intentions. Entrep. Theory Pract. 2009, 33, 593-617. [CrossRef]

52. Turner, S.L.; Alliman-Brissett, A.; Lapan, R.T.; Udipi, S.; Ergun, D. The Career-Related Parent Support Scale. Meas. Eval. Couns. Dev. 2003, 36, 83-94. [CrossRef] 
53. Nelson, T.; Constantinidis, C. Sex and Gender in Family Business Succession Research: A Review and Forward Agenda From a Social Construction Perspective. Fam. Bus. Rev. 2017, 30, 219-241. [CrossRef]

54. Cadieux, L.; Lorrain, J.; Hugron, P. Succession in women-owned family businesses: A case study. Fam. Bus. Rev. 2002, 15, 17-30. [CrossRef]

55. Kolvereid, L. Prediction of Employment Status Choice Intentions. Entrep. Theory Pract. 1996, 21, 47-58. [CrossRef]

56. Mathews, C.H.; Moser, S.B. Family background and gender: Implications for interest in small firm ownership. Entrep. Reg. Dev. 1995, 7, 365-378. [CrossRef]

57. Chen, C.C.; Greene, P.G.; Crick, A. Does entrepreneurial self-efficacy distinguish entrepreneurs from managers? J. Bus. Ventur. 1998, 13, 295-316. [CrossRef]

58. Boyd, N.G.; Vozikis, G.S. The Influence of Self-Efficacy on the Development of Entrepreneurial Intentions and Actions. Entrep. Theory Pract. 1994, 18, 63-77. [CrossRef]

59. Zhao, H.; Seibert, S.E.; Hills, G.E. The Mediating Role of Self-Efficacy in the Development of Entrepreneurial Intentions. J. Appl. Psychol. 2005, 90, 1265-1272. [CrossRef] [PubMed]

60. George, J.M.; Zhou, J. When openness to experience and conscientiousness are related to creative behavior: An interactional approach. J. Appl. Psychol. 2001, 86, 513-524. [CrossRef] [PubMed]

61. Luthje, C.; Franke, N. The 'making' of an entrepreneur: Testing a model of entrepreneurial intent among engineering students at MIT. RED Manag. 2003, 33, 135-147. [CrossRef]

62. Salamzadeh, A.; Farjadian, A.A.; Amirabadi, M.; Modarresi, M. Entrepreneurial characteristics: Insights from undergraduate students in Iran. Int. J. Entrep. Small Bus. 2014, 21, 165. [CrossRef]

63. Tkachev, A.; Kolvereid, L. Self-employment intentions among Russian students. Entrep. Reg. Dev. 1999, 11, 269-280. [CrossRef]

64. Veciana, J.M.; Aponte, M.; Urbano, D. University Students' Attitudes Towards Entrepreneurship: A Two Countries Comparison. Int. Entrep. Manag. J. 2005, 1, 165-182. [CrossRef]

65. Podsakoff, P.M.; MacKenzie, S.B.; Lee, J.-Y.; Podsakoff, N.P. Common method biases in behavioral research: A critical review of the literature and recommended remedies. J. Appl. Phycol. 2003, 88, 879-903. [CrossRef]

66. Podsakoff, P.M.; Organ, D.W. Self-Reports in Organizational Research: Problems and Prospects. J. Manag. 1986, 12, 531-544. [CrossRef]

67. Bontis, N.; Booker, L.D.; Serenko, A. The mediating effect of organizational reputation on customer loyalty and service recommendation in the banking industry. Manag. Decis. 2007, 45, 1426-1445. [CrossRef]

68. Drengner, J.; Gaus, H.; Jahn, S. Does Flow Influence the Brand Image in Event Marketing? J. Advert. Res. 2008, 48, 138-147. [CrossRef]

69. Gruber, M.; Heinemann, F.; Brettel, M.; Hungeling, S. Configurations of resources and capabilities and their performance implications: An exploratory study on technology ventures. Strateg. Manag. J. 2010, 31, 1337-1356. [CrossRef]

70. Sattler, H.; Völckner, F.; Riediger, C.; Ringle, C.M. The impact of brand extension success drivers on brand extension price premiums. Int. J. Res. Mark. 2010, 27, 319-328. [CrossRef]

71. Chua, J.H.; Chrisman, J.J.; Sharma, P. Defining the Family Business by Behavior. Entrep. Theory Pract. 1999, 23, 19-39. [CrossRef]

72. Ruiz, J.M.; Vallejo, M.M.; Martínez, J.R. Organizational harmony as a value in family businesses and its influence on performance. J. Bus. Ethics 2013, 126, 259-272. [CrossRef]

73. Segaro, E.L.; Larimo, J.; Jones, M.V. Internationalization of family small and medium sized enterprises: The role of stewardship orientation, family commitment culture and top management team. Int. Bus. Rev. 2014, 23, 381-395. [CrossRef]

74. Vallejo, M.C. Analytical Model of Leadership in Family Firms Under Transformational Theoretical Approach. Fam. Bus. Rev. 2009, 22, 136-150. [CrossRef]

75. Binz, C.; Patel, V.K.; Wanzenried, G. A comparative study of CB-SEM and PLS-SEM for theory development in family firm research. J. Fam. Bus. Strategy 2014, 5, 116-128.

76. Sarstedt, M.; Ringle, C.M.; Smith, D.; Reams, R.; Hair, J.F., Jr. Partial least squares structural equation modeling (PLS-SEM). Eur. Bus. Rev. 2014, 26, 106-121. [CrossRef]

77. Wittmann, C.M.; Hunt, S.D.; Arnett, D.B. Explaining alliance success: Competences, resources, relational factors, and resource-advantage theory. Ind. Mark. Manag. 2009, 38, 743-756. [CrossRef] 
78. Chin, W.W.; Newsted, P.R. Structural equation modeling analysis with small samples using partial least squares. Stat. Strateg. Small Sample Res. 1999, 1, 307-341.

79. Hulland, J. Use of partial least squares (PLS) in strategic management research: A review of four recent studies. Strateg. Manag. J. 1999, 20, 195-204. [CrossRef]

80. Roldán, J.L.; Leal, A. A validation test of an adaptation of the DeLone and McLean's model in the Spanish EIS field. In Critical Reflections on Information Systems. A Systemic Approach; IGI Global: Hershey, PA, USA, 2003; pp. 66-84.

81. Carmines, E.G.; Zeller, R.A. Reliability and Validity Assessment; Sage Publications, Inc.: Thousand Oaks, CA, USA, 1979; Volume 17.

82. Chin, W.W. The partial least squares approach for structural equation modeling. In Modern Methods for Business Research; Marcoulides, G.A., Ed.; Lawrence Erlbaun Associates: Mahwah, NJ, USA, 1998; pp. $295-336$.

83. Hundleby, J.D.; Nunnally, J. Psychometric Theory. Am. Educ. Res. J. 1968, 5, 431. [CrossRef]

84. Fornell, C.; Larcker, D.F. Evaluating structural equation models with unobservable variables and measurement error. J. Mark. Res. 1981, 18, 39-50. [CrossRef]

85. Becker, J.-M.; Klein, K.; Wetzels, M. Hierarchical Latent Variable Models in PLS-SEM: Guidelines for Using Reflective-Formative Type Models. Long Range Plan. 2012, 45, 359-394. [CrossRef]

86. Dawson, A.; Sharma, P.; Irving, P.G.; Marcus, J.; Chirico, F. Predictors of Later-Generation Family Members' Commitment to Family Enterprises. Entrep. Theory Pract. 2013, 39, 545-569. [CrossRef]

87. Goldberg, S.D.; Wooldridge, B. Self-Confidence and Managerial Autonomy: Successor Characteristics Critical to Succession in Family Firms. Fam. Bus. Rev. 1993, 6, 55-73. [CrossRef]

88. De Massis, A.; Foss, N.J. Advancing Family Business Research: The Promise of Microfoundations. Fam. Bus. Rev. 2018, 31, 386-396. [CrossRef]

89. Alonso, A.D.; Kok, S.; O'Shea, M. The family business, adversity and change: A dynamic capabilities and knowledge-based approach. J. Gen. Manag. 2019, 44, 96-109. [CrossRef]

90. Chirico, F.; Salvato, C. Knowledge Internalization and Product Development in Family Firms: When Relational and Affective Factors Matter. Entrep. Theory Pract. 2014, 40, 201-229. [CrossRef]

91. Chirico, F.; Sirmon, D.G.; Sciascia, S.; Mazzola, P. Resource orchestration in family firms: Investigating how entrepreneurial orientation, generational involvement, and participative strategy affect performance. Strateg. Entrep. J. 2011, 5, 307-326. [CrossRef]

92. Casprini, E.; De Massis, A.; Di Minin, A.; Frattini, F.; Piccaluga, A. How family firms execute open innovation strategies: The Loccioni case. J. Knowl. Manag. 2017, 21, 1459-1485. [CrossRef]

93. Faccin, K.; Balestrin, A.; Martins, B.V.; Bitencourt, C.C. Knowledge-based dynamic capabilities: A joint R\&D project in the French semiconductor industry. J. Knowl. Manag. 2019, 23, 439-465. [CrossRef]

94. Conz, E.; Magnani, G. A dynamic perspective on the resilience of firms: A systematic literature review and a framework for future research. Eur. Manag. J. 2020, 38, 400-412. [CrossRef] 